\title{
A CROSS SECTIONAL STUDY OF THE PREVALENCE OF BACTERIAL CONTAMINATION OF STETHOSCOPE DIAPHRAGMS AMONG HEALTH CARE PROVIDERS OF A TERTIARY CARE HOSPITAL
}

\author{
Rajeshwari Prabhakar Rao 1 \\ ${ }^{1}$ Associate Professor, Department of Microbiology, Srinivas Institute of Medical Sciences \& Research Centre.
}

\section{ABSTRACT}

The hospital environment is known to be one of the most pathologically dense microenvironments. Diaphragms of stethoscopes of doctors, nurses, medical students and other healthcare professionals harbour a variety of microorganisms. [1],[2],[3],[4],[5]

\section{KEYWORDS}

Stethoscope Diaphragms, Bacterial Contamination, Prevalence, Health Care Providers.

HOW TO CITE THIS ARTICLE: Rao RP. A cross sectional study of the prevalence of bacterial contamination of stethoscope diaphragms among health care providers of a tertiary care hospital. J. Evolution Med. Dent. Sci. 2016;5(33):1863-1864,

DOI: $10.14260 /$ jemds/2016/439

\section{INTRODUCTION}

Our main objective was to ascertain the mean load on the diaphragms and to compare the efficacy of a single alcohol swipe with that of distilled water, on stethoscope diaphragms on a sub-sample of the cohort pre- and post-cleaning. We sampled 220 stethoscopes from consenting consultants and medical students (Total of 180) and those used in the ward (40 numbers). Stethoscopes belonging to doctors who did not use it frequently (i.e. less than three times a day) were not included in the study. The other objectives were to compare the bacterial load on personal stethoscopes of categories of doctors, represented appropriately by stratified random sampling and ward stethoscopes.

Among the 180 stethoscopes of medical faculty, 100 samples were randomly selected for carrying out the comparison of efficacy of alcohol and distilled water. The 100 samples were randomly distributed into two groups of 50 each to test the efficacy of alcohol on one group and that of distilled water on the other group. The same method of cleaning was ensured for both the groups by the same operator. Stethoscope diaphragms were imprinted onto non-selective media (Blood agar), to grow aerobic bacteria and fungal pathogens, if present. Plates were incubated according to standard procedure for $18-24$ hours at $37^{\circ} \mathrm{C}$ and subsequent growth was identified by standard methods and number of colonies were counted as colony forming units (CFU).[6]

Growth within the impression area was considered as evidence for bacterial contamination and no growth on the area was considered as negative. Growth was quantified as heavy, moderate and scanty depending on the area of the impression-growing colonies. Complete growth within the impression was considered heavy. If colonies could be counted, it was considered as scanty.

Statistical analysis was done using SPSS version 16. Data obtained was not normally distributed; therefore, nonparametric tests were done.

Financial or Other, Competing Interest: None.

Submission 27-02-2016, Peer Review 31-03-2016,

Acceptance 06-04-2016, Published 25-04-2016.

Corresponding Author:

Dr. Rajeshwari Prabhakar Rao,

Associate Professor,

Department of Microbiology,

SIMS \& RC, Mukka,

Surathkal, Mangalore.

E-mail: dr.rajeshwariprao@gmail.com

DOI: $10.14260 /$ jemds/2016/439
We found that of the 220 stethoscopes sampled, 181 $(82 \%)$ had evidence of bacteria on the surface of the diaphragms. [Table 1] demonstrates that the reduction of colonies following cleaning either with alcohol or distilled water was significant and that the difference in their efficacy of cleaning was not statistically significant. We also found that all the stethoscopes used in the ward were contaminated and there was no difference in the degree of contamination among the personal stethoscopes of categories of doctors.

\begin{tabular}{|c|c|l|c|c|}
\hline $\mathbf{N}$ & $\begin{array}{c}\text { Mean CFU } \\
\text { Count }\end{array}$ & P Value & $\begin{array}{c}\text { Mean } \\
\text { CFU }\end{array}$ & $\begin{array}{c}\text { P } \\
\text { Value }\end{array}$ \\
\hline $\begin{array}{c}\text { Before } \\
\text { Alcohol } \\
50\end{array}$ & 15.41 & $<0.0001$ & $\begin{array}{c}\text { After } \\
\text { Alcohol } \\
44.11\end{array}$ & 0.012 \\
\hline $\begin{array}{c}\text { After } \\
\text { Alcohol } \\
50\end{array}$ & 1.51 & & & \\
\hline $\begin{array}{c}\text { Before } \\
\text { DW } \\
50\end{array}$ & 23.89 & & $\begin{array}{c}\text { After DW } \\
56.86\end{array}$ & \\
\hline $\begin{array}{c}\text { After DW } \\
50\end{array}$ & 6.81 & & & \\
\hline \multicolumn{4}{|c|}{ Table 1: Efficacy of Alcohol and Distilled } \\
Water after a Single Swipe \\
\hline
\end{tabular}

CFU: Colony forming units; DW: Distilled water

The reduction of colonies following cleaning with distilled water was also found to be statistically significant (Done using Wilcoxon signed ranks test).

No difference was found in the efficacy of cleaning by alcohol or distilled water.

A study conducted in St. John's Medical College, Bangalore and G B Pant Hospital, Delhi, found that $80 \%$ of the stethoscopes grew pathogens.[1],[7] Similar results were obtained in our study. In another study conducted in Slovakia, there was significant reduction in bacterial load after disinfection. ${ }^{[8]}$

We conclude that though stethoscopes are important tools for the doctors and nurses, the potential for contamination with skin flora is high. Stethoscope cleaning is not consciously done by the users. In the era of drug-resistant bacteria and the inanimate environment being a major reservoir of these bacteria, importance should be given to cleaning of stethoscopes because they enter the area of a "bed space." Inadequate or no cleaning will help in transmission of 
bacteria among patients within the hospital. This study demonstrates that a simple swipe with alcohol or distilled water can reduce microbial contamination. Either of the disinfectants could be used to reduce the bio-burden.

Cleaning of these inanimate objects after use would help in reducing transmission of organisms within the hospital [Figure 1 and Figure 2].

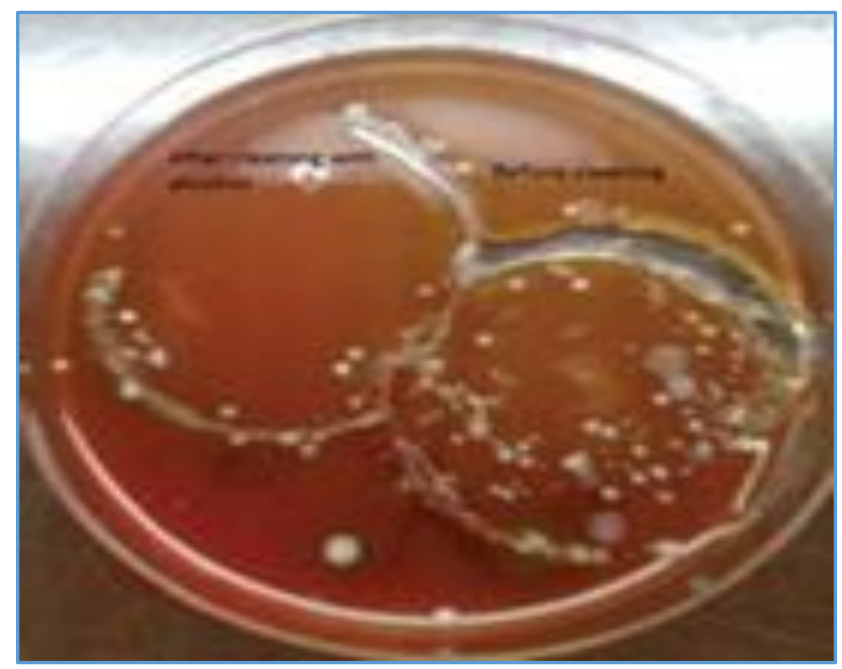

Fig. 1: Before and After Alcohol Swipe

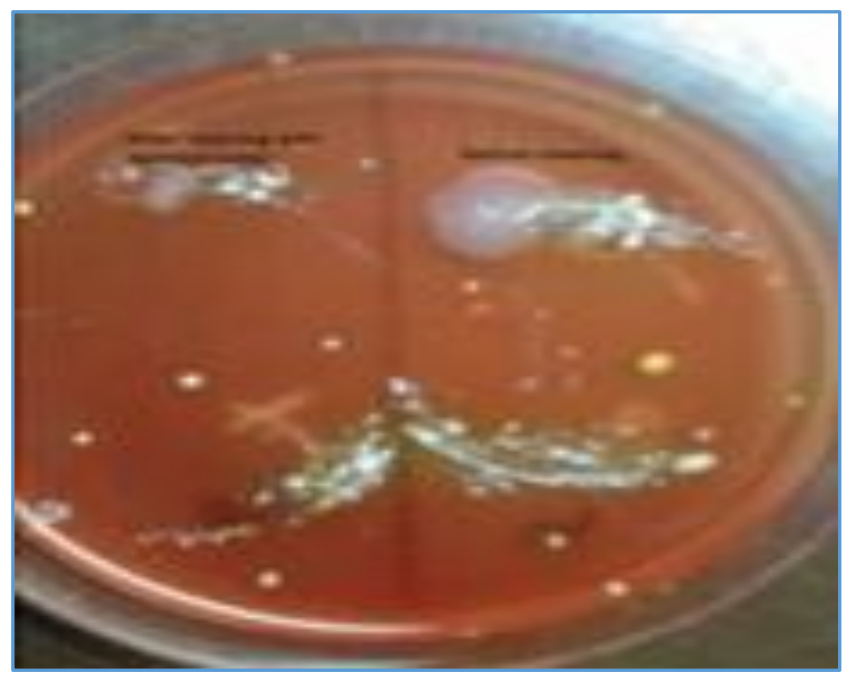

Fig. 2: Before and After Distilled Water Swipe

\section{REFERENCES}

1. Lokkur PP, Nagaraj S. The prevalence of bacterial contamination of stethoscope diaphragms: a crosssectional study, among health care workers of a tertiary care hospital. Indian J Med Microbiol 2014;32(2):201-02.

2. Datta P, Rani H, Chander J, et al. Bacterial contamination of mobile phones of health care

workers. Indian J Med Microbiol 2009;27(3):279-81.

3. Zachary KC, Bayne PS, Morrison VJ, et al. Contamination of gowns, gloves and stethoscopes with vancomycinresistant enterococci. Infect Control Hosp Epidemiol 2001;22(9):560-4.

4. Bernard L, Kerveur A, Durand D, et al. Bacterial contamination of hospital physicians' stethoscopes. Infect Control Hosp Epidemiol 1999;20(9):626-8.

5. Madar R, Novakova E, Baska T. The role of non-critical health-care tools in transmission of nosocomial infections. Bratisl Lek Litsey 2005;106(11):348-50.

6. Collee JG. Mackie and McCartney Practical Medical Microbiology. New York, Churchill Livingstone, $14^{\text {th }}$ ed.

7. Sood P, Mishra B, Mandal A. Potential infection hazards of stethoscopes. J Indian Med Assoc 2000;98(7):368-70.

8. Marinella MA, Pierson C, Chenoweth C. The stethoscope: a potential source of nosocomial infection? Arch Intern Med 1997;157(7):786-90. 